\title{
THE DEVELOPMENT OF LEARNING EQUIPMENT USED PBL IN SEQUENCE AND SERIES TO IMPROVE STUDENT'S HOTS
}

\author{
Cindy Kusumawati \\ Mathematics Education, Faculty of Mathematics and Natural Sciences, Universitas Negeri Surabaya \\ e-mail: cindykusumawati@mhs.unesa.ac.id \\ Siti Khabibah \\ Mathematics Education, Faculty of Mathematics and Natural Sciences, Universitas Negeri Surabaya \\ e-mail: sitikhabibah@unesa.ac.id
}

\begin{abstract}
This research is based on the lack of students' ability to answer the Higher Order Thinking Skills (HOTS) questions. This is shown from the survey results of TIMSS in 2015 which stated that Indonesia ranked 45 of 50 countries. Furthermore, the survey results of the PISA in 2015 showed that Indonesia's mathematical competence was 386 points of 600 points with a rating of 64 from 72 countries, therefore, to improving HOTS a Problem Based Learning model is needed (Rahmawati, 2016). The purpose of this study is to describe the process and results of the development of learning equipment used Problem Based Learning model in sequences and series material to improve HOTS of senior high school students. The type of this research is developmental research that uses the Plomp's Development model which consists of preliminary investigation phase, design phase, realization phase, and test, evaluation and revision phase. The research instrument used was a learning equipment validation sheet, an observation sheet of learning implementation, an assessment sheet, and a student questionnaire response sheet. This learning tools was tested to 32 students of XI MIPA-3 class at SMAN 1 Sidoarjo. The results of these development equipment are categorized very well (which is shown by the an average value of 4.30 for lesson plan, 4.28 for student's worksheet, 4.25 for assessment sheet range from 5.00), practical (which is shown by the average rating of the validator is a little revision and the implementation of learning in the excellent category with an average of 3.71), and effective (classical succeed is reached, Learning Outcome II is higher than Learning Outcome I, and student scores on HOTS questions number 1 on Test II is higher than score number 1(b) on Test I, and student response is positive). So, the learning equipment used Problem Based Learning model in sequences and series can improve HOTS of Senior High School students.
\end{abstract}

Keywords: Problem Based Learning, Higher Order Thinking Skills

\section{INTRODUCTION}

Permendikbud No. 59 tahun 2014 states that one of the competencies emphasized for senior high school graduate students in learning mathematics is to show a logical, critical, analytical, and creative attitude. These attitudes are needed to develop students' thinking abilities. The development of thinking skills develops from the lowest level to the highest level.

Higher Order Thinking Skills (HOTS) are the ability to think that consists of critical thinking, creative thinking, and problem solving (Brookhart, 2010: 3). The importance of HOTS in learning is also shown by the results of Murray's (2011: 210) which states that when students use HOTS then students decide what to believe and what to do, create new ideas, make predictions and solve problems that are not routine.

The fact in several surveys shows that Indonesian students' HOTS in learning mathematics are still classified as lower category. In 2015 TIMSS survey data shows that Indonesia ranked $45^{\text {th }}$ of 50 countries (Rahmawati, 2016). Furthermore, the results of the PISA survey in 2015 showed that Indonesia was ranked $64^{\text {th }}$ out of 72 countries (Kemdikbud, 2016). Therefore, improving HOTS required the ability of teachers to plan and manage effective learning. Effective teachers are teachers who have systematic preparation and implementation of learning. These preparations can be designed and organized into learning equipment. Meanwhile, to improve the implementation of learning required appropriate learning models and learning objectives.

One of the learning models that is suitable with the implementation of the 2013 curriculum and demands student activity is the Problem Based Learning (PBL) model. This is in accordance with Brookhart (2010: 5) which states that in improving students' HOTS, learning is needed that provides real problems in class, provides discussion and student involvement activities, conducts 
investigations, solves challenging problems, and shares ideas.

In this study, learning tools were developed for sequences and series material, because these materials are often found to solve real-life problems such as population growth and interest calculation.

Based on the explanation above, this research is done to know and describe the process and results of the development of learning equipment used Problem Based Learning model in sequence and series material to improve the HOTS of senior high school students.

\section{METHODOLOGY}

This type of research is development research that refers to the Plomp's model. The subjects in this study was students at XI-MIPA 3 and teachers at SMAN 1 Sidoarjo. While the objects in this study are the Lesson Plan (RPP), Student Activity Sheet (LKS), and Assessment Sheet (LP) using the Problem Based Learning model.

The stages of developing learning equipment can be presented in the following chart.

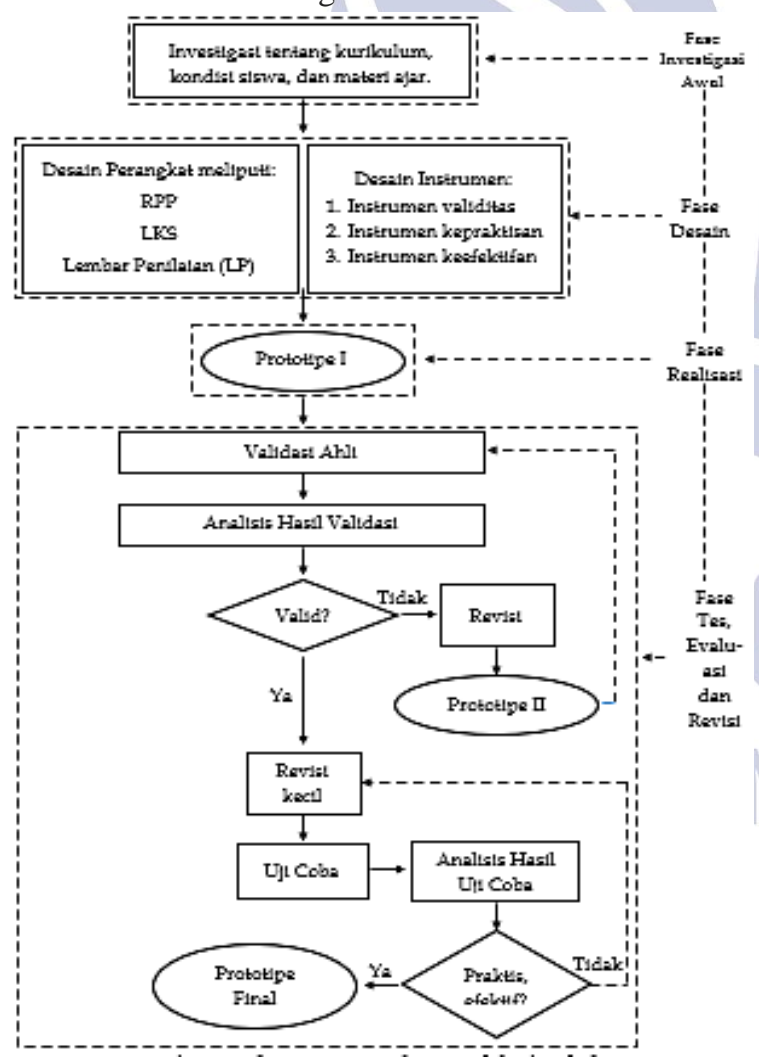

Chart 1. Stages of Developing Learning Equipment

The Plomp's model consists of five phases, namely preliminary investigation phase, design phase, realization/construction phase, test, evaluation, and revision phase, and implementation phase. However, in this research the implementation phase was not carried out because it required a considerable amount of time and process.
The research instruments used in collecting data include: (1) learning equipment validation sheets (2) observation sheets (3) test sheets (4) response sheets.

\section{Data collection techniques}

Data collection techniques in this study using a questionnaire, observation, and tests. The questionnaire was given to the validator, namely Dini Kinanti Fardah, S.Pd.Si, M.Pd and Evangelista Lus WP., S.Pd., M.Sc and also students of class XI MIPA-3. In this study the researcher as a teacher while the observator is the partner teacher, Drs. Dzulkifli Effendy, M.Pd to observe the implementation of learning. Data that is filled out by partner teachers then analyzed to determine the practicality of the learning equipment.

\section{Data Analysis Techniques}

Data Analysis Techniques consist of aspects of validity, practicality, and effectiveness. Validity analysis by finding the average of each criterion from all validators. Then look for the average of each aspect and total average. Thus, the validity category can be determined by matching the total average with the validity criteria adapted from Khabibah (2006). Practicality analysis is done by looking at the input and suggestions from the validator. The learning equipment is said to be practical if in theory, the validator states that the learning equipment can be used in the class with less or no revisions, which have been filled in on the learning device validation sheet. In addition, the practicality of the RPP results of minimal observations in the good or very good category. The device is said to be effective if it fulfills several things, namely: (1) classical learning mastery, in this study based on the score of students Test (THB). Classical learning mastery is achieved if $75 \%$ of students get a score of $\geq 75$ (2) student response data were categorized positively if the percentage who answered yes to learning activities as well as material and worksheets was $\geq 80 \%$ (3) HOTS increase, students are said to be complete if students reach the KKM score on the average score. Students are said to increase if the score of Test II is higher than Test I and the score of question number 1 on Test II is higher than the score of question number 1 (b) on Test I. So, HOTS students are said to increase if more than $75 \%$ of the number of students complete and increased (Gabby, 2012).

\section{RESEARCH DATA AND DISSCUSSION}

The results of this study is a description of the process and results of the development of learning equipment used Problem Based Learning model in sequence and series material to improve HOTS of senior high school students. The phases carried out and the results obtained in this study are explained as follows. 


\section{The Process of Learning Equipment Development}

1. Initial Investigation Phase

At this stage an analysis of the theories support, curriculum, student, and teaching materials.

2. Design phase

Based on the analysis of the initial investigation phase, the researcher conducted the preparation design of the learning equipment and research instruments.

3. Realization Phase

This phase is a continuation of the design phase. In this phase, the design that has been created is used as the foundation for making learning equipment and research instruments called prototype I. The prototype I consists of Lesson Plan (RPP), Student Activity Sheet (LKS), and Assessment Sheet (LP) using the Problem Based Learning model. The layout of the lesson plan can be seen as follows.

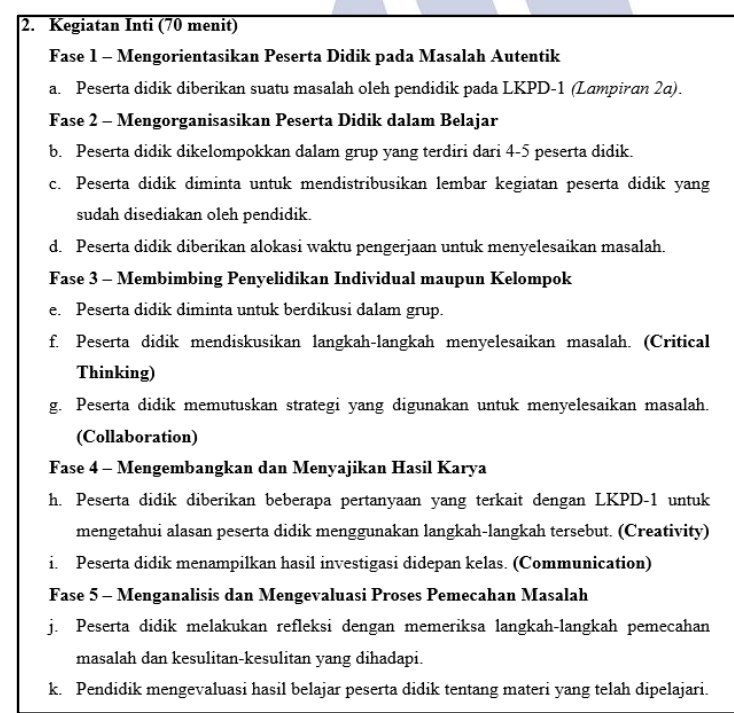

Picture 1. Lesson Plan

4. Test, Evaluation, and Revision Phase

In the implementation of the test, evaluation and revision phases, there are two stages, namely the validation of the learning device and the learning device trial. The results of the learning equipment validation are presented as follows.

Table 1. Learning Equipment Validation

\begin{tabular}{|c|c|c|c|c|c|}
\hline No. & \begin{tabular}{c|} 
Jenis \\
Perangkat
\end{tabular} & Aspek Penilaian & $\begin{array}{l}\text { Rata-rata } \\
\text { per Aspek }\end{array}$ & $\begin{array}{c}\text { Rata-rata } \\
\text { Total }\end{array}$ & $\begin{array}{l}\text { Kategori } \\
\text { Kevalidan }\end{array}$ \\
\hline \multirow{5}{*}{1.} & \multirow{5}{*}{ RPP } & Tujuan pembelajaran & 3,83 & \multirow{5}{*}{4,30} & \multirow{5}{*}{$\begin{array}{l}\text { Sangat } \\
\text { Valid }\end{array}$} \\
\hline & & Kegiatan pembelajaran & 4,67 & & \\
\hline & & Waktu & 4,75 & & \\
\hline & & Perangkat pembelajaran & 4,25 & & \\
\hline & & Sajian Bahasa & 4,00 & & \\
\hline \multirow{3}{*}{2.} & \multirow{3}{*}{ LKS } & Petunjuk & 4,50 & \multirow{3}{*}{4,28} & \multirow{3}{*}{$\begin{array}{l}\text { Sangat } \\
\text { Valid }\end{array}$} \\
\hline & & Isi & 4,00 & & \\
\hline & & Bahasa & 4,33 & & \\
\hline \multirow{3}{*}{3.} & \multirow{3}{*}{ LP } & Materi & 4,00 & \multirow{3}{*}{4,25} & \multirow{3}{*}{$\begin{array}{l}\text { Sangat } \\
\text { Valid }\end{array}$} \\
\hline & & Konstruksi & 4,50 & & \\
\hline & & Bahasa & 4,25 & & \\
\hline
\end{tabular}

Based on the results of the validation of the learning equipment above and the validity criteria, the Problem Based Learning model of the sequence and sequence material to improve the HOTS of senior high school students developed by researchers in the very valid category.

In addition, the two validators also gave general assessments and suggestions on the learning tools developed. The results of the validation and suggestions for the learning device are used as a reference for revising the prototype I learning device into a prototype II learning equipment that will be used for limited trials. The testing of learning devices using prototype II was carried out with the aim of testing the effectiveness of the learning devices developed. All prototype II materials both learning devices and research instruments were tested on 32 students of class XI SMAN 1 Sidoarjo. The results of the observation sheet of learning implementation as follows.

Table 2. Observation Sheet of Learning Implementation

\begin{tabular}{|l|c|}
\hline $\begin{array}{c}\text { Langkah-langkah } \\
\text { pembelajaran }\end{array}$ & $\boldsymbol{K}_{\boldsymbol{y}}$ \\
\hline Pendahuluan & 3,67 \\
\hline Kegiatan Inti & 3,88 \\
\hline Penutup KM & 3,58 \\
\hline \multicolumn{1}{|c|}{$\mathbf{3 , 7 1}$} \\
\hline
\end{tabular}

The performance total average of learning is 3.71 . Based on the criteria, the implementation of learning in the very practical category. Because the implementation of learning in the category is very practical and the general assessment of the RPP of the two validators is B which means it can be used with a little revision, it can be concluded that the device equipment is practical.

\section{The Result of Learning Equipment Development}

Based on student test score data and completeness criteria there are $78.13 \%$ students (25 students) who complete the requirements. So, it can be concluded that HOTS students have improved. Thus, the learning equipment developed in this study complete the aspects of validity, practicality, and effectiveness. Therefore, the learning equipment in the sequence and series material developed in this study is a good tool and can improve the HOTS of senior high school students then it is called the Final Prototype. 


\section{CONCLUSION AND SUGGESTION}

\section{Conclusion}

Based on the data analysis that has been done by the researcher, it can be concluded as follows.

1. The development of learning equipment used Plomp's model that consists of five phases, namely preliminary investigation phase, design phase, realization/ construction phase, test, evaluation, and revision phase, and implementation phase. However, in this research the implementation phase was not carried out because it required a considerable amount of time and process.

2. The learning equipment developed in this study complete the aspects of validity, practicality, and effectiveness. Therefore, the learning equipment in the sequence and series material developed in this study is a good tool and can improve the HOTS of senior high school students.

\section{Suggestion}

Based on the research result and conclusion that have been mentioned, so the researcher suggests that the teacher should make a learning equipment as the learning equipment developed from researcher in other material such then it can be other learning sources in Problem Based Learning process.

\section{REFERENCES}

Brookhart, S.M. 2010. How to Asess Higher Order Thingking Skills in Your Classroom. Alexanderia, VA: ASCD.

Gaby, Mc. Donald. 2012. Teaching Critical and Analitical Thinking in High School Biology. The American Biology Teacher.

Rahmawati. 2016. Seminar Hasil TIMMS 2015: Diagnosa Hasil untuk Perbaikan Mutu dan Peningkatan Capaian.

Kemendikbud. 2014. Peraturan Materi Pendidikan dan Kebudayaan Nomor 59, Tahun 2013, tentang Kurikulum 2013 Sekolah Menengah Atas/ Madrasah Aliyah.

Kemendikbud. 2016. Peringkat dan Capaian PISA Indonesia Mengalami Peningkatan.

Khabibah, Siti. 2006. Pengembangan Model Pembelajaran Matematika dengan Soal Terbuka untuk Meningkatkan Kreativitas Siswa Sekolah Dasar. Disertasi. Tidak dipublikasikan. Surabaya: Doktoral Universitas Negeri Surabaya.

Murray, E., C. 2011. Implementing Higher-Oder Thingking in Middle School Mathematics Classrooms. Dissertation Submitted to the Graduate Faculty of the University of Georgia.

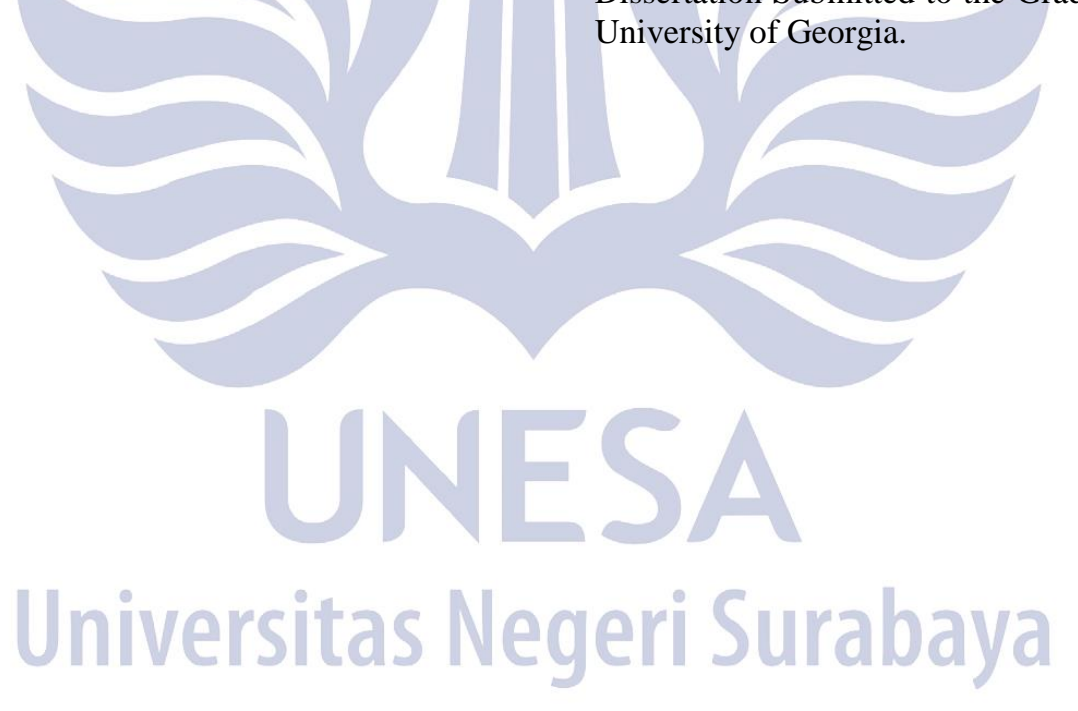

